\title{
Validation of the Self-report altruism scale test in Colombian University Students*
}

\author{
Validación de la prueba de escala de altruismo \\ Self-report en estudiantes universitarios colombianos
}

Teste de validação escala de auto-relatório altruismo em estudantes universitários

Received 21 april 2016. Accepted 16 november 2016

\begin{abstract}
, Para citar este artículo:
Aguilar Pardo, David y Martínez

Cotrina, Jorge (diciembre,

2016). Validation of the

Self-report altruism scale

test in Colombian University

Students. Ánfora, 23(41), 17 -

35. Universidad Autónoma de

Manizales. ISSN 0121-6538
\end{abstract}

\author{
David Aguilar Pardo** \\ Colombia \\ Jorge Martínez Cotrina*** \\ Colombia
}

\section{Abstract}

Objective: to establish whether the Canadian selfreport altruism scale questionnaire is a reliable estimate for altruistic behavior in young Colombian university students. Methodology: the self-report altruism scale test was adapted and applied. 327 university students between 18 and 25 years from five independent cohorts participated in this study. Participants should note, in 20 items, the frequency (never, once, more than once, often

\footnotetext{
* This article was developed from an investigation that was proposed to adapt the Canadian questionnaire "the self-report altruism scale" for the population of Colombian university students. It began in January 2013 and was completed in December 2014. The research had the backing of the Universidad Católica de Colombia and the Universidad Externado de Colombia. It is currently complete.

** PhD Candidate in psychology. Magister in ethology and animal physiology. DEA in animal and human ethology. Biologist. Professor at the psychology department of the Universidad Católica de Colombia. Email: draguilar@ucatolica.edu.co

*** PhD Candidate in social studies. Magister in environmental management for sustainable development. Degree in chemistry and biology. Researcher of the group Salud, conocimiento médico y sociedad. Centro de investigaciones sobre dinámica social CIDS. Facultad de Ciencias Sociales y Humanas. Unviersidad Externado de Colombia.Email: jorgea.martinez@uexternado.edu.co
} 
or very often) with which they performed altruistic behavior. The method of this study followed the protocol of the World Health Organization for these cases. There was also a correlation analysis between the score of the questionnaire and the evaluation that some close friends of each participant made in relation to the altruistic tendency of the latter. Results: cronbach's alpha, bipartition analysis and comparison of these data with those reported in other countries show that the instrument is highly reliable. The selfreport altruism scale questionnaire is a useful tool to estimate the altruistic behavior of Colombian university students. Conclusions: the relevance of developing tools to assess prosocial behavior in the country is discussed and clarified. Expanding the age range and applying the questionnaire to non-university populations, will strengthen the development of the instrument.

Keywords: Altruism, Prosociality, University students, Validation.

\section{Resumen}

Objetivo: establecer si el cuestionario canadiense the self-report altruism scale es una herramienta confiable para estimar el comportamiento altruista en jóvenes universitarios colombianos. Metodología: se adaptó y aplicó el test the self-report altruism scale. Participaron 327 universitarios entre los 18 y 25 años, distribuidos en cinco cohortes independientes. Los participantes debían señalar, en 20 ítems, la frecuencia (Nunca, una vez, más de una vez, frecuentemente o muy frecuentemente) con la que realizan comportamientos altruistas. El método de este estudio siguió el protocolo de la Organización Mundial de la Salud para estos casos. Se hizo también un análisis de correlación entre el puntaje de cuestionario y la evaluación que hicieron algunos amigos cercanos de cada participante en relación con la tendencia altruista de este último. Resultados: se evidenció que el instrumento es altamente confiable. El cuestionario the self-report altruism scale es una herramienta útil para estimar el comportamiento altruista de jóvenes universitarios colombianos. Conclusiones: se discute y aclara la pertinencia de desarrollar herramientas que evalúen los comportamientos prosociales en el país. Ampliar el rango de edad y aplicar el cuestionario a poblaciones no universitarias, fortalecerá el desarrollo del instrumento.

Palabras clave: Altruismo; Prosocialidad; Universitarios; Validación. 


\section{Resumo}

Objetivo: estabelecer se o questionário canadense the self-report altruism scale é uma ferramenta confiável para estimar o comportamento altruísta em jovens universitários colombianos. Metodologia: o teste the self-report altruism scale foi adaptado e aplicado. Participaram do teste 327 universitários entre 18 e 25 anos, distribuídos em cinco grupos independentes. Os participantes deviam sinalar em 20 itens, a frequência (Nunca, uma vez, mais de uma vez, frequentemente ou muito frequentemente) com a que realizam comportamentos altruístas. $\bigcirc$ método deste estudo seguiu o protocolo da Organização Mundial da Saúde para estes casos. Também foi feita uma análise de correlação entre a pontuação de questionário e a avaliação que fizeram alguns amigos próximos de cada participante em relação com a tendência altruísta deste ultimo. Resultados: o alfa de Cronbach, uma análise de bipartição e a comparação destes dados com os reportados em outros países, evidencia que o instrumento é altamente confiável. O questionário the self-report altruism scale é uma ferramenta útil para estimar o comportamento altruísta de jovens universitários colombianos Conclusões: discute-se e aclara a pertinência de desenvolver ferramentas que avaliem os comportamentos pró-sociais no país. Ampliar a categoria de idade e aplicar o questionário a populações não universitárias fortalecerá o desenvolvimento do instrumento.

Palavras-chave: Altruísmo, Pró-sociabilidade, Universitários, Validação. 


\section{Introduction}

Prosocial behaviors, understood as those that go to benefit others (Dunfield and Kuhlmeier, 2013) have been identified in various biological entities (Foster, 2011; Hauser, McAuliffe and Blake, 2009) and are the key to long-term preservation within many species. Among the variety of ways that prosociality is expressed, altruism is particularly striking because it implies that an individual voluntarily incurs in any cost in order to benefit another (Leontopoulou, 2010). For this reason human altruism is a recurring topic of debate in history (Kahn, 1981; Kant, 1991), even more, when the relation of altruism with many of the pillars of human societies as ethics, religion, politics, education and coexistence is recognized.

Evolutionary and cognitive models that attempt to account for this behavior in the animal kingdom have been developed. According to the theory of kin selection (Hamilton, 1964), animals develop behaviors that put them at risk or lead to sacrifice only when it comes to their families, increasing their genetic potential. In addition, reciprocal altruism (Trivers, 1971) proposes that the sacrifice is worth it in the long term, because in the future altruistic behavior can be paid back. While there are criticisms about the evidence of reciprocal altruism in other animals (Hauser, McAuliffe and Blake, 2010), this type of altruism clearly works in human societies (Bereczkei, Birkas and Kerekes, 2010).

Now, although altruistic behaviors are widely distributed in the animal kingdom, the way humans express it is unique in nature (Fehr and Fischbacher Gächter, 2002). For example, humans are the only species that exhibit what is called strong altruism, which refers to the tendency to reward altruistic behavior and punish non-altruists, even if that reward or punishment involves a significant cost to the person who exerts it (Fehr and Fischbacher, 2003). Warneken and Tomasello (2009) suggest the existence of a natural predisposition in humans to perform altruistic behavior that emerges early in ontogeny, before socialization has an important impact on the development of children (Warneken and Tomasello, 2007); surprisingly, strengthening altruistic behaviors can have a negative effect against that predisposition (Warneken and Tomasello, 2008).

In addition, many non-human primates have prosocial tendencies that allow to suggest that the phylogenetic roots of human altruism, at least in the form of instrumental help, can be traced to the last common ancestor of humans and chimpanzees, about six million years ago (Warneken and Tomasello, 2009). 
Interdisciplinary studies have elucidated some aspects of altruistic behavior. There has been significant progress in understanding the cognitive processes involved (Blake et al, 2014; Aguilar-Pardo, Martínez-Arias and Colmenares, 2013; Rand Greene and Nowak, 2012), its relationship with other prosocial behaviors (Svetlova, Nichols and Brownel, 2010; Warneken and Tomasello, 2007), the interaction with socio-emotional aspects (Menesini, Palladino and Nocentini, 2015; Curry and Dunbar, 2013), its development (Sebastian Enesco, Hernández-Lloreda and Colmenares, 2013 ; House, 2012), its evolution (Vogt et al, 2015;. Fehrler and Przepiorka, 2013; Henrich et al, 2010), its relationship with the genetic substrate (Sibly and Curnow, 2011) and its interaction with environmental factors (Aponte Martinez and Caicedo, 2016) among others.

However, many of the fundamental questions about prosociality and altruism in particular remain unresolved; for this reason these issues will be on the main research topics of contemporary science (Pennisi, 2005). Therefore, the development and strengthening of instruments to quantify altruistic behavior is essential, in order to deal with systematic and reliable hypothesis methodologies.

In Colombia, there are no validated instruments to measure altruistic behavior; so the following question arises: Is the Self-report Altruism Scale (Rushton, Chrisjohn and Fekken, 1981) a tool that can potentially be used to estimate altruistic behavior in Colombia? This questionnaire of 20 questions was developed in Canada and has proven useful in various studies (Rushton et al., 2007; Krueger, 2001; Johnson et al., 1998; Chou, 1996). Its adaptation to Colombia contributes to the development of research around prosocial behavior, a field of study that is at the forefront of contemporary science and that is key to the development of strategies aimed at strengthening a peaceful coexistence in the country, more important, when a lasting peace in Colombia is expected according to the expectations of the end of armed conflict.

Therefore, this paper aims at adapting the instrument as a useful tool to make inferences regarding the altruistic behavior of college students and assessing its reliability, that is to say, to prove that the instrument has no significant measurement errors. All this in order to contribute to the study of prosocial behaviors in the Colombian context and generate opening for future research where it is relevant to evaluate altruistic behavior among university students. Moreover, this work potentially contributes to the future development of the instrument in other parts of the world. 


\section{Methodology}

The self-report altruism scale test was applied. It was composed by 20 items in which subjects had to indicate the frequency with which they performed altruistic behavior. Each question was written short and clearly to facilitate its application and adaptation. For the latest, the steps recommended by the World Health Organization in these cases were followed: 1) official translation of the questionnaire, 2) modification by experts to suit the local population, 3) piloting, 4) evaluation of the piloting; 5) Application and 6) re-translation to the original language.

First, one of the authors of the questionnaire was consulted. He agreed to the procedure and followed the process closely. With this guarantee, it became an official translation of the original document which was discussed by a committee of experts who made some modifications to contextualize the text to the particular conditions of the Colombian population. To finish the translation process, as amended by the experts' version, it was re-translated into English in order to include all four versions (original questions, official translation, translation modified by experts and reverse translation), in the final document (Table 1).

Table 1: Original version and translation and adaptation process for the altruism questionnaire: "The Self-Report Altruism Scale" for the Colombian population.

\begin{tabular}{|c|c|c|c|}
\hline Original Question & Official translation & $\begin{array}{c}\text { Modification } \\
\text { by experts }\end{array}$ & $\begin{array}{l}\text { Reverse } \\
\text { translation }\end{array}$ \\
\hline $\begin{array}{l}\text { Tick the category } \\
\text { on the right that } \\
\text { conforms to the } \\
\text { frequency with } \\
\text { which you have } \\
\text { carried out the } \\
\text { following acts. }\end{array}$ & $\begin{array}{l}\text { Marque a la derecha } \\
\text { la elección que } \\
\text { se conforma a la } \\
\text { frecuencia con la } \\
\text { cual usted ha llevado } \\
\text { a cabo las siguientes } \\
\text { acciones. }\end{array}$ & $\begin{array}{l}\text { Marque con una X } \\
\text { en la columna de la } \\
\text { derecha, la opción } \\
\text { que mejor refleje la } \\
\text { frecuencia con la } \\
\text { cual usted ha llevado } \\
\text { a cabo las siguientes } \\
\text { acciones. }\end{array}$ & $\begin{array}{l}\text { Place an } X \text { in the } \\
\text { right-hand column } \\
\text { next to the actions } \\
\text { which you have } \\
\text { done before. }\end{array}$ \\
\hline $\begin{array}{l}\text { Never, Once, More } \\
\text { than once, Often, } \\
\text { Very often. }\end{array}$ & $\begin{array}{l}\text { Nunca, Una Vez, } \\
\text { Más de Una Vez, Fre- } \\
\text { cuentemente, Muy } \\
\text { Frecuentemente. }\end{array}$ & $\begin{array}{l}\text { Nunca, Una Vez, } \\
\text { Más de Una Vez, Fre- } \\
\text { cuentemente, Muy } \\
\text { Frecuentemente. }\end{array}$ & $\begin{array}{l}\text { Never, Once, More } \\
\text { than once, Often, } \\
\text { Very often. }\end{array}$ \\
\hline
\end{tabular}




\begin{tabular}{|c|c|c|c|c|}
\hline & Original Question & Official translation & $\begin{array}{l}\text { Modification } \\
\text { by experts }\end{array}$ & $\begin{array}{l}\text { Reverse } \\
\text { translation }\end{array}$ \\
\hline 1 & $\begin{array}{l}\text { I have helped push } \\
\text { a stranger's car out } \\
\text { of the snow. }\end{array}$ & $\begin{array}{l}\text { He ayudado a un } \\
\text { desconocido a } \\
\text { empujar su carro } \\
\text { varado. }\end{array}$ & $\begin{array}{l}\text { He ayudado a un } \\
\text { desconocido a } \\
\text { empujar su carro } \\
\text { varado. }\end{array}$ & $\begin{array}{l}\text { Have helped a } \\
\text { stranger push his } \\
\text { broken-down car. }\end{array}$ \\
\hline 2 & $\begin{array}{l}\text { I have given direc- } \\
\text { tions to a stranger. }\end{array}$ & $\begin{array}{l}\text { Le he dado indica- } \\
\text { ciones a un descono- } \\
\text { cido en la calle. }\end{array}$ & $\begin{array}{l}\text { Le he dado indica- } \\
\text { ciones a un descono- } \\
\text { cido en la calle. }\end{array}$ & $\begin{array}{l}\text { Have given direc- } \\
\text { tions to a stranger } \\
\text { lost in the street. }\end{array}$ \\
\hline 3 & $\begin{array}{l}\text { I have made chan- } \\
\text { ge for a stranger. }\end{array}$ & $\begin{array}{l}\text { Le he cambiado un } \\
\text { billete a un desco- } \\
\text { nocido. }\end{array}$ & $\begin{array}{l}\text { Le he cambiado un } \\
\text { billete a un descono- } \\
\text { cido por sencillo. }\end{array}$ & $\begin{array}{l}\text { Have made change } \\
\text { for a stranger. }\end{array}$ \\
\hline 4 & $\begin{array}{l}\text { I have given money } \\
\text { to a charity. }\end{array}$ & $\begin{array}{l}\text { He donado dinero } \\
\text { a instituciones de } \\
\text { caridad. }\end{array}$ & $\begin{array}{l}\text { He donado dinero } \\
\text { a instituciones de } \\
\text { caridad. }\end{array}$ & $\begin{array}{l}\text { Have donated } \\
\text { money to charity. }\end{array}$ \\
\hline 5 & $\begin{array}{l}\text { I have given money } \\
\text { to a stranger who } \\
\text { needed it (or asked } \\
\text { me for it). }\end{array}$ & $\begin{array}{l}\text { Le he dado dinero a } \\
\text { un desconocido que } \\
\text { lo necesitaba (o que } \\
\text { lo solicitó). }\end{array}$ & $\begin{array}{l}\text { Le he dado dinero a } \\
\text { un desconocido que } \\
\text { lo necesitaba (o que } \\
\text { me lo pidió). }\end{array}$ & $\begin{array}{l}\text { Have given money } \\
\text { to a stranger who } \\
\text { needed (or asked } \\
\text { for) it. }\end{array}$ \\
\hline 6 & $\begin{array}{l}\text { I have donated } \\
\text { goods or clothes to } \\
\text { a charity. }\end{array}$ & $\begin{array}{l}\text { He donado bienes o } \\
\text { ropa a instituciones } \\
\text { de caridad. }\end{array}$ & $\begin{array}{l}\text { He donado bienes o } \\
\text { ropa a instituciones } \\
\text { de caridad. }\end{array}$ & $\begin{array}{l}\text { Have donated } \\
\text { good or clothing to } \\
\text { charity. }\end{array}$ \\
\hline 7 & $\begin{array}{l}\text { I have done vo- } \\
\text { lunteer work for a } \\
\text { charity. }\end{array}$ & $\begin{array}{l}\text { He trabajado de } \\
\text { voluntario en institu- } \\
\text { ciones de caridad. }\end{array}$ & $\begin{array}{l}\text { He trabajado como } \\
\text { voluntario en institu- } \\
\text { ciones de caridad. }\end{array}$ & $\begin{array}{l}\text { Have volunteered } \\
\text { in charity organiza- } \\
\text { tions. }\end{array}$ \\
\hline 8 & $\begin{array}{l}\text { I have donated } \\
\text { blood. }\end{array}$ & He donado sangre. & He donado sangre. & Have given blood. \\
\hline 9 & $\begin{array}{l}\text { I have helped } \\
\text { carry a stranger's } \\
\text { belongings (books, } \\
\text { parcels, etc.). }\end{array}$ & $\begin{array}{l}\text { Le he ayudado a un } \\
\text { desconocido con sus } \\
\text { pertenencias (libros, } \\
\text { paquetes, etc.) }\end{array}$ & $\begin{array}{l}\text { Le he ayudado a un } \\
\text { desconocido a car- } \\
\text { gar sus pertenencias } \\
\text { (libros, paquetes, } \\
\text { etc.). }\end{array}$ & $\begin{array}{l}\text { Have helped a } \\
\text { stranger carry } \\
\text { things (books, } \\
\text { packages, etc.). }\end{array}$ \\
\hline 10 & $\begin{array}{l}\text { I have delayed an } \\
\text { elevator and held } \\
\text { the door open for a } \\
\text { stranger. }\end{array}$ & $\begin{array}{l}\text { He detenido el } \\
\text { ascensor y abierto } \\
\text { la puerta para un } \\
\text { desconocido. }\end{array}$ & $\begin{array}{l}\text { He detenido el } \\
\text { ascensor y abierto la } \\
\text { puerta para que un } \\
\text { desconocido alcance } \\
\text { a entrar. }\end{array}$ & $\begin{array}{l}\text { Have stopped the } \\
\text { elevator to hold } \\
\text { the door open for a } \\
\text { stranger. }\end{array}$ \\
\hline 11 & $\begin{array}{l}\text { I have allowed so- } \\
\text { meone to go ahead } \\
\text { of mein a lineup (at } \\
\text { Xerox machine, in } \\
\text { the supermarket). }\end{array}$ & $\begin{array}{l}\text { Le he cedido mi } \\
\text { puesto en fila a otra } \\
\text { persona (en el su- } \\
\text { permercado, banco, } \\
\text { etc.). }\end{array}$ & $\begin{array}{l}\text { Le he cedido mi } \\
\text { puesto en la fila a } \\
\text { otra persona (en } \\
\text { el supermercado, } \\
\text { banco, fotocopiado- } \\
\text { ra, etc.). }\end{array}$ & $\begin{array}{l}\text { Have given my } \\
\text { place in line to } \\
\text { another person (at } \\
\text { the supermarket, } \\
\text { bank, etc.). }\end{array}$ \\
\hline
\end{tabular}




\begin{tabular}{|c|c|c|c|c|}
\hline & Original Question & Official translation & $\begin{array}{l}\text { Modification } \\
\text { by experts }\end{array}$ & $\begin{array}{l}\text { Reverse } \\
\text { translation }\end{array}$ \\
\hline 12 & $\begin{array}{l}\text { I have given a } \\
\text { stranger a lift in } \\
\text { my car. }\end{array}$ & $\begin{array}{l}\text { Le he dado a un } \\
\text { desconocido un } \\
\text { aventón }\end{array}$ & $\begin{array}{l}\text { He llevado en mi } \\
\text { carro a un descono- } \\
\text { cido. }\end{array}$ & $\begin{array}{l}\text { Have driven a } \\
\text { stranger in my car. }\end{array}$ \\
\hline 13 & $\begin{array}{l}\text { I have pointed } \\
\text { out a clerk's error } \\
\text { (in a bank, at the } \\
\text { supermarket) in } \\
\text { undercharging me } \\
\text { for an item. }\end{array}$ & $\begin{array}{l}\text { Le he explicado al } \\
\text { cajero su error (en el } \\
\text { banco, supermerca- } \\
\text { do, etc.) cuando me } \\
\text { dio dinero de más. }\end{array}$ & $\begin{array}{l}\text { Le he explicado } \\
\text { al cajero su error } \\
\text { cuando me ha dado } \\
\text { dinero de más (en el } \\
\text { banco, supermerca- } \\
\text { do, etc.). }\end{array}$ & $\begin{array}{l}\text { Have told the } \\
\text { cashier she made a } \\
\text { mistake when she } \\
\text { gave me too much } \\
\text { money (at the bank, } \\
\text { supermarket, etc). }\end{array}$ \\
\hline 14 & $\begin{array}{l}\text { I have let a neigh- } \\
\text { bour whom I didn't } \\
\text { know too well } \\
\text { borrow an item of } \\
\text { some value to me } \\
\text { (e.g., a dish, tools, } \\
\text { etc.). }\end{array}$ & $\begin{array}{l}\text { Le he prestado a un } \\
\text { vecino a quien no } \\
\text { conozco bien, un } \\
\text { artículo que tiene } \\
\text { valor para mi (e.g. } \\
\text { bandejas, herra- } \\
\text { mientas, etc.) }\end{array}$ & $\begin{array}{l}\text { Le he prestado a un } \\
\text { vecino a quien no } \\
\text { conozco bien, un ar- } \\
\text { tículo que tiene valor } \\
\text { para mí (ej. bandejas, } \\
\text { herramientas, etc.). }\end{array}$ & $\begin{array}{l}\text { Have lent some- } \\
\text { thing valuable to } \\
\text { a neighbor I didn't } \\
\text { know well (tools, } \\
\text { etc). }\end{array}$ \\
\hline 15 & $\begin{array}{l}\text { I have bought } \\
\text { 'charity' Christmas } \\
\text { cards deliberately } \\
\text { because I knew it } \\
\text { was a good cause. }\end{array}$ & $\begin{array}{l}\text { He comprado pro- } \\
\text { ductos hechos por } \\
\text { entidades de caridad } \\
\text { pensando que tienen } \\
\text { una buena causa. }\end{array}$ & $\begin{array}{l}\text { He comprado pro- } \\
\text { ductos hechos por } \\
\text { entidades de caridad } \\
\text { pensando que los } \\
\text { fondos son para una } \\
\text { buena causa. }\end{array}$ & $\begin{array}{l}\text { Have bought } \\
\text { products from } \\
\text { charieties thinking } \\
\text { the proceeds go to } \\
\text { a good cause. }\end{array}$ \\
\hline 16 & $\begin{array}{l}1 \text { have helped a } \\
\text { classmate who } \\
1 \text { did not know } \\
\text { that well with } \\
\text { a homework } \\
\text { assignment when } \\
\text { my knowledge was } \\
\text { greater than his or } \\
\text { hers. }\end{array}$ & $\begin{array}{l}\text { Le he ayudado a un } \\
\text { compañero de clase } \\
\text { a quien no conocía } \\
\text { bien, con tareas } \\
\text { cuando yo sabía más } \\
\text { que él/ella. }\end{array}$ & $\begin{array}{l}\text { Le he ayudado con } \\
\text { sus tareas a un } \\
\text { compañero de clase } \\
\text { a quien no conocía } \\
\text { bien, cuando yo } \\
\text { sabía más que él o } \\
\text { ella. }\end{array}$ & $\begin{array}{l}\text { Have helped a } \\
\text { classmate I didn't } \\
\text { know well with } \\
\text { homework, when I } \\
\text { knew more than he } \\
\text { or she did. }\end{array}$ \\
\hline 17 & $\begin{array}{l}\text { I have before being } \\
\text { asked, voluntarily } \\
\text { looked after a } \\
\text { neighbour's pets } \\
\text { or children without } \\
\text { being paid for it. }\end{array}$ & $\begin{array}{l}\text { Antes de que me } \\
\text { lo soliciten, me he } \\
\text { ofrecido para cuidar } \\
\text { las mascotas o los } \\
\text { hijos de los vecinos, } \\
\text { sin que me paguen. }\end{array}$ & $\begin{array}{l}\text { Antes de que me } \\
\text { lo soliciten, me he } \\
\text { ofrecido para cuidar } \\
\text { las mascotas o los } \\
\text { hijos de los vecinos, } \\
\text { sin que me paguen. }\end{array}$ & $\begin{array}{l}\text { Have offered } \\
\text { to care for my } \\
\text { neighbor's pets or } \\
\text { children for free. }\end{array}$ \\
\hline 18 & $\begin{array}{l}\text { I have offered to } \\
\text { help a handicapped } \\
\text { or elderly stranger } \\
\text { across a street. }\end{array}$ & $\begin{array}{l}\text { Le he ofrecido } \\
\text { ayuda a una persona } \\
\text { discapacitada, o de } \\
\text { tercera edad, para } \\
\text { cruzar la calle. }\end{array}$ & $\begin{array}{l}\text { Le he ofrecido } \\
\text { ayuda a una persona } \\
\text { discapacitada o de } \\
\text { la tercera edad para } \\
\text { cruzar la calle. }\end{array}$ & $\begin{array}{l}\text { Have helped a disa- } \\
\text { bled or old person } \\
\text { cross the street. }\end{array}$ \\
\hline
\end{tabular}




\begin{tabular}{|c|c|c|c|c|}
\hline & Original Question & Official translation & $\begin{array}{l}\text { Modification } \\
\text { by experts }\end{array}$ & $\begin{array}{l}\text { Reverse } \\
\text { translation }\end{array}$ \\
\hline 19 & $\begin{array}{l}\text { I have offered my } \\
\text { seat on a bus or } \\
\text { train to a stranger } \\
\text { who was standing. }\end{array}$ & $\begin{array}{l}\text { Le he cedido mi silla } \\
\text { en el bus o en el tren } \\
\text { a un desconocido } \\
\text { que estaba de pie. }\end{array}$ & $\begin{array}{l}\text { Le he cedido mi silla } \\
\text { en el bus a un des- } \\
\text { conocido que estaba } \\
\text { de pie. }\end{array}$ & $\begin{array}{l}\text { Have given up your } \\
\text { seat on the bus for } \\
\text { a stranger. }\end{array}$ \\
\hline 20 & $\begin{array}{l}\text { I have helped an } \\
\text { acquaintance to } \\
\text { move households. }\end{array}$ & $\begin{array}{l}\text { Le he ayudado a } \\
\text { un conocido en su } \\
\text { mudanza. }\end{array}$ & $\begin{array}{l}\text { Le he ayudado a } \\
\text { un conocido con su } \\
\text { trasteo o mudanza. }\end{array}$ & $\begin{array}{l}\text { Have helped a } \\
\text { friend move. }\end{array}$ \\
\hline
\end{tabular}

Source: the author

After the modifications suggested by the Committee and before the application of the instrument, a piloting session with 20 women and 20 men allowed a first assessment of internal behavior of the test. Fairly consistent results were shown (see Table 1), which is why it was decided not to make additional modifications to the questionnaire.

Piloting and implementation were carried out with university students between 18 and 25 years old, the same range as that used in Canada, where the questionnaire was originally developed. In addition to the 40 participants of the piloting, the instrument was applied to 287 people in four cohorts $(n=$ $67, \mathrm{n}=70, \mathrm{n}=86$ and $\mathrm{n}=64)$. The application in each cohort was conducted independently on different days, at two universities in Bogotá.

Emulating the Canadian procedure, the questionnaire was also applied to some friends of the participants who evaluated the frequency with which the participant (not themselves) performed the behaviors described in the questionnaire. This allowed comparing the participants' self-report, with what their peers thought of them. For the rating of each couple, it was taken into account that they were at least three friends, also university students and who were in the same age range of the sample. This procedure was performed with a subset of 201 people who attended the call the day of the application of the instrument.

Because each of the possible answers is equal to a value (never $=1$, once $=2$, more than once $=3$, often $=4$ and very often $=5$ ), at the end of the questionnaire a result between 20 and 100 is given, which comes from the sum of the 20 questions and where a higher number represents a greater tendency to altruistic behavior. This quantification made possible to calculate the mean and standard deviation for each cohort, and the corresponding Cronbach's alpha. 
Similarly, a bipartition analysis per cohort was performed, and finally the values of the correlation between self-report and score pairs were estimated. All these data were compared when possible, with populations of Canada and China, for which the questionnaire was also adapted.

\section{Results}

The average scores and standard deviations of the questionnaire in each cohort, plus the values of Cronbach's alpha and bipartite analysis are presented here. (Table 2). It continues with the comparison between self-report and peer evaluation (Fig.1) and the analysis continues with the comparison between genders, in relation to each question. In the end, the scope and limitations of this study are discussed and some strategies for strengthening the instrument in the future are proposed.

The average for population of this study in the questionnaire was 47.41 with standard deviation $=9.99(\mathrm{n}=327)$. In Canada these values were found $\mathrm{M}=55.66$ and $\mathrm{SD}=10.37(\mathrm{n}=420)$, while the Chinese study does not report these data. To evaluate the consistency of the instrument, the Cronbach's alpha test was calculated, whose value was 0.82 (0.83 and 0.86 in Canada and China respectively). To confirm the above result, the coefficient of bipartition was also calculated, whose value after the Spearman-Brown correction was $0.85 ; \mathrm{p}$ $<0.001$. In the Chinese study, this coefficient was 0.82 while in the Canadian study this coefficient was not calculated. By discriminating cohorts, means and standard deviations were similar and both Cronbach's alpha coefficient as bipartition remained high (Table 1). 
Table 24. Means, standard deviations and reliability data for the questionnaire, in each of the samples.

\begin{tabular}{lccccc}
\hline & Pilotage & cohort 1 & cohort 2 & cohort 3 & cohort 4 \\
\hline Size & 40 & 67 & 70 & 86 & 64 \\
No. of Women & 20 & 38 & 43 & 53 & 39 \\
No. of Men & 20 & 29 & 27 & 33 & 25 \\
Global Average & 43,73 & 44,21 & 46,01 & 47,65 & 47,17 \\
Standard deviation & 10,96 & 10,44 & 9,67 & 9,28 & 12,43 \\
Alpha coefficient & 0,82 & 0,75 & 0,83 & 0,79 & 0,89 \\
Bipartition coefficient & 0,85 & 0,83 & 0,83 & 0,84 & 0,88 \\
Mean women (W) & 41,2 & 43,82 & 47,42 & 47,85 & 48,69 \\
Standard deviation W & 10,77 & 10,45 & 9,65 & 9,24 & 12,24 \\
Mean men (M) & 46,27 & 44,7 & 43,78 & 47,33 & 44,80 \\
Standard deviation M & 10,98 & 10,59 & 9,46 & 9,48 & 12,61 \\
\hline
\end{tabular}

Source: the author

The values for the correlation between self-report and peer evaluation were: $\mathrm{r}=0.44 ; \mathrm{p}<0.001 ; \mathrm{n}=201$ (Fig.1), which are comparable with those reported for the Canadian population: $\mathrm{r}=0.35 ; \mathrm{p}<0.001 ; \mathrm{n}=78$.

In China, the peer evaluation in the study was not included. In the present study there was no difference in the overall score related to gender or age; however, differences between men and women were found in three of the questions, Question $1(Z=-4,433, p<0.001)$, question $17(Z=-3,119 ; p=0.002)$ and Question $20(\mathrm{Z}=-2.723, \mathrm{p}=0.006)$.

Figure 1. Score on the questionnaire (self-report) 


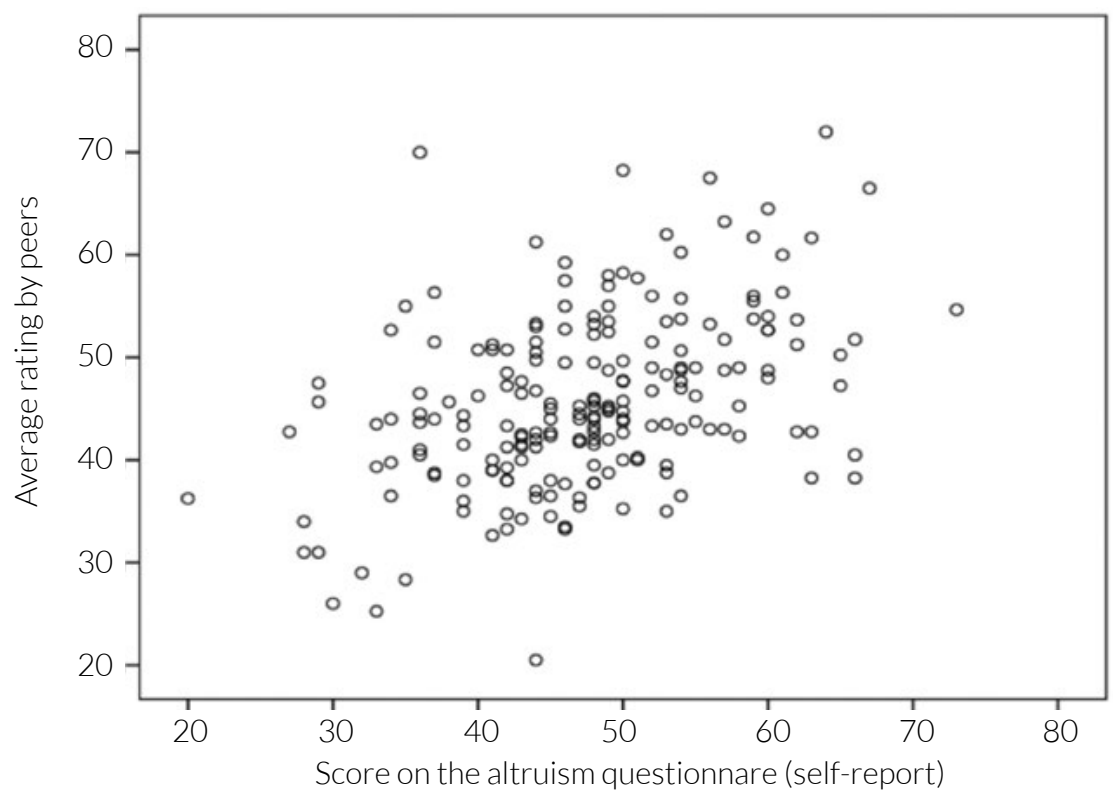

Evaluation by the peers against the own score on the altruism questionnaire (the self-report altruism scale). Participants who reported a higher frequency of altruistic behavior, were also evaluated by their peers as more altruistic, which contributes to the validity of the instrument. The correction between the two measures was significant $(r=0.44, p<0.001 ; n=201)$.

Source: author.

The results of Cronbach's alpha and the bipartition coefficient in the Colombian sample, show that there are no significant errors of measurement; it is to say, the questionnaire showed a high consistency (Santisteban, 1999) which confirms it as a reliable instrument. In other words, it always measures the same (Cortada, 1999). Comparisons with Canadian and Chinese populations reinforce these findings, as the three studies agree that the outcome of the questionnaire does not depend on gender. In addition, only in the Chinese population was there a correlation between the total score and age, which can be explained by the fact that the age range included in this work (11-28 years), was different to that used in Canada and Colombia (18-25).

The values of correlation between self-reported and peer evaluation, indicate that what the participants reported coincides with the perception of close people 
to those participants, which contributes to the validity of the test, suggesting that the questionnaire is useful and suitable to make inferences (Messick, 1980). This is reinforced by the fact that the correlation values are similar in Canada and Colombia and also because the $\mathrm{n}=201 \mathrm{used}$ in this study was even greater than that used in Canada, $n=78$. In future works the questionnaire could be applied in conjunction with another established questionnaire or one under construction that reflects altruistic behavior, to assess the relationship between instruments and thus to continue contributing to the validity of this scale of altruism.

As for the differences found between genders, men scored higher on questions involving physical strength, question 1 and 20, while women did the same in question 17 , related to child care. These differences are perfectly understandable and show that the instrument is sensitive to women. Neither the Chinese nor the Canadian study reported the comparison between questions taking into account gender and their authors indicate that these data are no longer available.

The study of altruistic behavior allowed advancement in the human cognition field (Benozio and Diesendruck, 2015), in the ontogenetic development (Aguilar et al, 2013.), in the evolution of our species (Yilmaz and Bahçekapili, 2016; Chiang and $\mathrm{Wu}, 2015$ ) and in the generation of public policies (Sloan, 2009; Gintis, 2000) among others. For these purposes, it is important to develop and strengthen tools that allow quantification. The Self-report-altruism-scale is one of the few instruments created for this purpose; its usefulness has been confirmed in several countries, as does this work for Colombia.

As altruism is one of the foundations of peaceful coexistence, its study supported by instruments such as the Self-report-altruism-scale questionnaire is a priority in Colombia, taking into account the expectations of the end of armed conflict. In this scenario, the adaptation that was done in this research contributes to the study of altruism and other forms of prosocial behavior in the country.

Collectively, the results of this study show that self-report altruism scale is useful in assessing altruistic behavior and that the use of this is feasible in Colombian university populations. After this adaptation, future studies could extend the age range of participants and applying the questionnaire in conjunction with personality tests to continue contributing to the consolidation of the instrument. 
Working with university students gave us the opportunity to compare the results of this study with those found in Canada, where the questionnaire was originally developed also with university students. However, it is appropriate to apply the instrument to populations with other levels of education, to assess how this variable affects the expression of altruistic behavior. Moving in these directions, this questionnaire will be strengthened as a tool for the study of prosocial behaviors that are pillars for sustaining human societies.

\section{Conclusions}

It is concluded that the adaptation of the Self-report altruism-scale questionnaire for Colombian university students has a high reliability because its behavior was similar in all cohorts. In addition to the translation, the tool did not suffer significant changes allowing the comparison between Colombian populations with other English speakers.

The correlation between self-reported and peer evaluation, in addition to comparisons with Chinese and Canadian populations suggest that the instrument is valid to measure altruistic behavior. Since in Colombia there are no validated instruments that consider this test will be useful for researches interested in the study of altruistic behavior.

The result of the questionnaire did not depend on gender at least in the age range with which it was worked ( 18 to 25 years), in the analyzed population (college students). These limitations were assumed because originally the questionnaire was applied in Canadian populations with the same characteristics and the comparison of similar populations was within the objectives of this adaptation. However, these restrictions do not give a guarantee that the application of the questionnaire is useful in populations with other characteristics.

For this reason, expanding the age range and estimating the reliability of the questionnaire in populations with different educational levels, it is in our goals to overcome these limitations and consolidation of the instrument. Similarly, the future development of other tools for the quantification of altruistic behavior will contribute to the validity of this questionnaire.

Finally, the study of altruistic behavior is recognized as a priority for further progress in the knowledge of human nature and social organization, especially when you consider the violent history of Colombia and the expectations of the 
end of armed conflict. Build effective strategies for peaceful coexistence in the country also involves the scientific study of the prosocial behavior; at this point in which this study has a significant impact.

\section{Acknowledgments}

The authors thank Cynthia Fekken, one of the authors of the original questionnaire for her cooperation; Juan Carlos Caicedo, Miguel Uribe and Carolina Valencia, for participating in the committee of experts; Geraldine Moreno, Juliana Alvarez, Nicolas Ferreira, Daniel Neira, Marcela Parra, Tatiana Quiroga and Sebastian Rozo, research guiders that contributed to the fieldwork; Ernesto Ardila and Anna Miller, for performing the official translation and retranslation and Angela Fonseca for their assistance in preparing the manuscript.

\section{References}

Aguilar, D., Martínez, R. and Colmenares, F. (2013). The role of inhibition in young children's altruistic behaviour. Cognitive Processing, (14), 301-307. Retrieved from doi: 10.1007/s 10339-013-0552-6

Aponte, M., Martínez, J. and Caicedo, J. (2016). Explorando el cerebro social: Expresiones desde la cooperación y la agresión en niños y jóvenes. Bogotá: Universidad Externado de Colombia.

Benozio, A. and G. Diesendruck. (2015). Parochialism in preschool boys' resource allocation. Evolution and Human Behavior, (36), 256-264. Retrieved from doi: http://dx.doi.org/10.1016/j.evolhumbehav.2014.12.002

Bereczkei, T., Birkas, B. and Kerekes, Z. (2010). Altruism towards strangers in need: Costly signaling in an industrial society. Evolution and Human Behavior,(31), 95-103. Retrieved from doi:10.1016/j.evolhumbehav.2009.07.004

Blake, P., Piovesan, M., Montinari, N., Warneken, F. and Gino, F. (2014). Prosocial norms in the classroom: The role of self-regulation in following norms of giving. Journal of Economic Behavior E Organization, (115), 18-29. Retrieved from doi:10.1016/j.jebo.2014.10.004 
Chiang, Y. and Wu, C. (2015). Social influence and the adaptation of parochial altruism: a dictator-game experiment on children and adolescents under peer influence. Evolution and Human Behavior, (36), 430-437. Retrieved from doi: http://dx.doi.org/10.1016/j.evolhumbehav.2015.03.007

Cortada, N. (1999). Teorías psicométricas y construcción de tests. Buenos Aires.

Chou, Kee-Lee. (1996). The Rushton, Chrisjohn and Fekken self-report altruism scale: A Chinese translation. Personality and Individual Differences, (21), 297-298.

Curry, O. and Dunbar, R. (2013). Sharing a joke: The effects of a similar sense of humor on affiliation and altruism. Evolution and Human Behavior, (34), 125-129. Retrieved from http://dx.doi.org/10.1016/j.evolhumbehav.2012.11.003

Dunfield, K. and Kuhlmeier, A. (2013). Classifying prosocial behavior: Children's responses to instrumental need, emotional distress, and material desire. Child Development, (84), 1766-1776. Retrieved from doi: 10.1111/ cdev. 12075

Fehr, E. and Fischbacher, U. (2003). The nature of human altruism. Nature, (425), 785-791. Retrieved from doi: 10.1038/nature02043

Fehr, E., Fischbacher, U. and Gächter, S. (2002). Strong reciprocity, human cooperation, and the enforcement of social norms. Human Nature, (13), 1-25. Retrieved from doi: $10.1007 / \mathrm{s} 12110-002-1012-7$

Fehrler, S. and Przepiorka, W. (2013). Charitable giving as a signal of trustworthiness: Disentangling the signaling benefits of altruistic acts. Evolution and Human Behavior, (34), 139-145. http://dx.doi.org/10.1016/j.evolhumbehav.2012.11.005

Foster, K. (2011). The sociobiology of molecular systems. $\underline{\text { Nature Reviews Gene- }}$ tics, (12), 193-203. doi:10.1038/nrg2903

Gintis, H. (2000). Strong reciprocity and human sociality. J. theor. Biol., (206), 169-179.

Hamilton, W. (1964). The genetical evolution of social behavior. Journal of theorical boilogy, (7), 1-16. 
Hauser, M., McAuliffe,K. and Blake, P. (2009). Evolving the ingredients for reciprocity and spite. Philosophical Transactions of The Royal Society B, (364), 3255-3266. Retrieved from doi: 10.1098/rstb.2009.0116

Henrich, J., Ensminger, J., McElreath, R., Barr, A., Barrett, C., Bolyanatz, A., Cardenas, J., Gurven, M., Gwako, E., Henrich, N., Lesorogol, C., Marlowe, F., Tracer, D. and Ziker, J. (2010). Markets, religion, community size, and the evolution of fairness and punishment. Science, (327), 1479-1484. Retrieved from doi: 10.1126/science. 1182238

House, B., Henrich, J., Brosnan, S. and Silk, J. (2012). The ontogeny of human prosociality: Behavioral experiments with children aged 3 to 8. Evolution and Human Behavior, (33), 291-308. Retrieved from doi:10.1016/j.evolhumbehav.2011.10.007

Johnson, R. C. G. P. Danko., T. J. Darvill, S. Bochner, J. K. Bowers, Y.-H. Huang, J. Y. Park, V. Pecjak, A. R. A. Rahim and D. Pennington. (1989). Cross-cultural assessment of altruism and its correlates. Personality and Individual Differences, (10), 855-868.

Kahn, C. (1981). Aristotle and altruism. Mind, (90), 20-40.

Kant, I. (1991). The metaphysics of morals. Cambridge: Cambridge University Press.

Krueger, R., Hicks, B. and McGue, M. (2001). Altruism and antisocial behavior: Independent tendencies, unique personality correlates, distinct etiologies. Psychological Science, (12), 397-402.

Leontopoulou, S. (2010). An exploratory study of altruism in Greek children: Relations with empathy, resilience and classroom climate. Psychology, (1), 377-385. Retrieved from doi: 10.4236/psych.2010.15047

Menesini, E., Palladino, B. and Nocentini, A. (2015). Emotions of moral disengagement, class norms, and bullying in adolescence: A multilevel approach. Merrill- Palmer Quarterly, (61), 124-143. Retrieved from doi: 10.13110/ merrpalmquar 1982.61.1.0124

Messick, S. (1980). Test validity and the ethics of assessment. American Psychologist, (35), 1012-27. 
Pennisi, E. (2005). How did cooperative behavior evolve? Science, (309), 93.

Rushton, P., Chrisjohn, R. and Fekken, C. (1981). The altruistic personality and the self-report altruism scale. Personality and Individual Differences, (2), 293-302.

Rushton, P., Vernon, P. and Bons, T. (2007). No evidence that polymorphisms of brain regulator genes Microcephalin andASPM are associated with general mental ability, head circumference or altruism. Biology Letters, (3), 157-160. Retrieved from doi:10.1098/rsbl.2006.0586

Rand, D., Greene, J. and Nowak, M. (2012). Spontaneous giving and calculated greed. Nature, (489), 427-430. Retrieved from doi: 10.1038/nature 1467.

Sebastián-Enesco, C., Hernández-Lloreda, M. and Colmenares, F. (2013). Two and a half-year-old children are prosocial even when their partners are not. Journal of Experimental Child Psychology, (116), 186-198. Retrieved from http://dx.doi.org/10.1016/j.jecp.2013.05.007

Santisteban C. (1999). Psicometría. Teoría y práctica en la construcción de tests. Madrid, España: ed. Norma.

Sibly, R. and Curnow, R. (2011). Selfishness and altruism can coexist when help is subject to diminishing returns. Heredity, (107), 167-173. Retrieved from doi:10.1038/hdy.2011.2

Sloan, D., D. Tumminelli and A. Sesma. (2009). Human prosociality from an evolutionary perspective: variation and correlations at a city-wide scale. Evolution and Human Behavior, (30), 190-200. Retrieved from doi: 10.1016/j. evolhumbehav.2008.12.002

Svetlova, M., Nichols, S. and Brownell, C. (2010). Toddlers' prosocial behavior: From instrumental to empathic to altruistic helping. Child Development, (81), 1814-1827. Retrieved from doi: 10.1111/j.1467-8624.2010.01512.x

Trivers, R. (1971). The evolution of reciprocal altruism. The Quarterly Review of Biology, (46), 35-57. 
Vogt, S., Efferson, C., Berger, J. and Fehr, F. (2015). Eye spots do not increase altruism in children. Evolution and Human Behavior, (36), 224-231. Retrieved from http://dx.doi.org/10.1016/j.evolhumbehav.2014.11.007

Warneken, F. and Tomasello, M. (2009). The roots of human altruism. British Journal of Psychology, (100), 455-471. Retrieved from doi 10.1348/000712608X379061

Warneken, F. and Tomasello, M. (2008). Extrinsic rewards undermine altruistic tendencies in 20-Month-Olds. Developmental Psychology, (44), 1785-1788. Retrieved from doi: 10.1037/a0013860

Warneken, F. and Tomasello, M. (2007). Helping and cooperation at 14 months of age. Infancy,(1 1),271-294. Retrieved fromdoi: 10.1348/00071260SX379061

Yilmaz, O. and Bahçekapili, H. (2016) Supernatural and secular monitors promote human cooperation only if they remind of punishment. Evolution and Human Behavior, (37), 79-84. doi: http://dx.doi.org/10.1016/j.evolhumbehav.2015.09.005 